\title{
ECOLOGIA POLITICA DESDE LA AMAZONIA ECUATORIANA: VOLVER AL TERRITORIO DESPUÉS DE LA PANDEMIA DEL COVID 19
}

\author{
ECOLOGIA POLÍTICA NA AMAZÔNIA EQUATORIANA: RETORNAR \\ AO TERRITÓRIO DEPOIS DA PANDEMIA DE COVID 19
}

José Efraín Astudillo Banegas ${ }^{1}$

https://orcid.org/0000-0003-4152-1657

Recebido em: 29 de maio de 2020

Aprovado em: 20 de julho de 2020

RESUMEN. La sociedad experimenta una pandemia de COVID 19, como resultado del mal desarrollo implementado por el sistema capitalista, que, entre otras cosas en estas últimas décadas, a sobre explotado el suelo y ha invadido inmisericordemente los hábitats de los animales salvajes, generando desigualdades en contra de los propios objetivos del desarrollo, que es terminar con la pobreza. La sensibilidad y la sensatez pueden ser entre otros los caminos para que la humanidad enferma, vuelva a cuidar la relación humana - naturaleza, a través de la cual se develan, en este caso particular, en las experiencias narradas en la cultura Shuar la buena producción y alimentación que permite la salud y una espiritualidad que permite a los pobladores Vivir Bien.

Palabras clave: Mal desarrollo. Territorio. Interculturalidad. Buena vida. Amazonía.

RESUMO: A sociedade vive a pandemia de COVID 19, como resultado do mau desenvolvimento implementado pelo sistema capitalista, que, entre outras coisas nestas últimas décadas, super-explorou a terra e invadiu impiedosamente os habitats de animais, gerando desigualdades que vão contra os próprios objetivos declarados do desenvolvimento, que é acabar com a pobreza. A sensibilidade e a sensatez podem ser os caminhos para que a humanidade volte a cuidar da relação humanidade-natureza, por meio da qual se revelem, neste caso particular, as experiências narradas na cultura Shuar de uma boa produção e boa alimentação que permita a saúde e uma espiritualidade que permite aos moradores viver bem.

Palavras-chave: Mau Desenvolvimento. Território. Interculturalidade. Bem-Viver. Amazônia.

\footnotetext{
${ }^{1}$ Docente y Investigador en la Universidad de Cuenca - Ecuador. Magister en gestión de redes territoriales para el desarrollo sustentable y doctor en sociología y antropología por la Universidad Complutense de Madrid - España. Miembro del grupo de investigación interuniversitario Tierra; miembro del Consejo Nacional Anticorrupción - Azuay, miembro de la Junta promotora para la Universidad Amazónica - Morona Santiago. Profesor de Sociología Rural, Sociología Ambiental, Economía Social y Solidaria y Teorías del Desarrollo. Email: jose.astudillob@ucuenca.edu.ec.
} 


\section{EL DESARROLLO QUE ENFERMÓ EL TERRITORIO}

Si bien la industrialización per ce según Hobsbawm (1980, p. 73): "no tiene como fin último el desarrollo de la humanidad, sino la acumulación de capital a través de la plusvalía"; funciona entonces como pretexto para esclavizar a las personas, implementar la maquinaria para producir en masa y abaratar los productos en el mercado y establecer un modelo de desarrollo que perjudica a la dignidad humana y a la salud de las personas y del planeta.

En el Ecuador, la industria es el sueño de la continua explotación colonial, más que de la emergencia de una nueva clase social industrial, pues "la nueva república nació sobre las bases de explotación económica, social y étnica de los indígenas" (Ayala, 1993, p.70)

La dominación colonial continuó en el Ecuador "republicano de 1830". Las prácticas de subordinación racial, el cobro de tributos y la esclavización de los nativos en las grandes propiedades de los criollos, se mantuvo; el "tributo indígena representó la continuidad de la dominación colonial. Las invasiones abiertas a tierras coloniales y los nuevos mecanismos para sujetar a los indios a las haciendas" (Acosta, 1997, p.31). Mientras en Europa la revolución industrial, posibilitó la emergencia de la burguesía como nueva clase social, con un pensamiento moderno; en el Ecuador se continuó con una mentalidad colonial y la hacienda como medio de acumulación económica.

La industria ecuatoriana es heredera de una larga producción textil, con el hilado y los tejidos desde la época incásica. Los colonizadores y posteriormente las oligarquías que heredaron el poder, mantuvieron esta tradición para implementar la industria textil, junto al calzado, cabuya y sombreros de paja toquilla, sin embargo, con la apertura a productos europeos en el siglo XIX, esta industria entra en crisis. A finales del S. XIX se implementaron algunas empresas sobre todo en la transformación de la caña de azúcar, hilanderías, de cigarrillos y de cervezas (Paredes, 1985).

La aspiración del Estado ecuatoriano de alcanzar un desarrollo autónomo quedó trunca, debido a que los grupos dominantes continuaron con su proceso de acumulación vinculados al desarrollo manufacturero de los países centrales y a las alianzas que se establecieron entre los grupos dominantes históricamente, con la nueva burguesía con tintes de modernidad. "A través de estos, explícitos o implícitos el Estado transfirió en estos años masivamente excedentes a las burguesías urbano-oligopólicas" (Acosta, 2012, p. 140).

La industria ecuatoriana carece de sentido emancipador con una nueva matriz productiva y de un eje de acumulación propia, se mantiene la dependencia de las clases dominantes locales y del mercado internacional. Aunque el presidente Alfaro dictará la ley de protección industrial en 1906, para impulsar la modernización económica, incentivando la industria a través de terrenos cedidos a empresarios, exención de impuestos, preferencia en la utilización de recursos hídricos, reformas aduaneras, grandes obras de ingeniería como el ferrocarril que unió la costa con la sierra, reformas migratorias; la industrialización no paso de ser un intento, que aún se mantiene como el ideal de desarrollo nacional.

\section{LA DESIGUALDAD COMO ENFERMEDAD DEL MAL DESARROLLO}

En el contexto internacional de la división del trabajo a mediados del siglo XIX el Ecuador intenta industrializar el sector agrícola con la producción de cacao, que tuvo su éxito a finales del siglo XIX, junto a otros productos de exportación como la tagua, caucho, café y cueros, 
"la demanda de cacao y de otros productos tropicales en el mercado mundial, fue factible por el incremento del ingreso de amplios sectores de la población europea y luego norteamericana" (Acosta, 2012, p.59).

La escasa inversión que se requería para la producción, la riqueza de los suelos, así como del clima favorable para el cultivo de la fruta tropical, desarrolló una etapa cacaotera que lograría más tarde conjuntamente con el banano una integración nacional a través del desarrollo del mercado interno. Fueron las grandes haciendas del litoral que concentraron la propiedad del suelo en pocas manos, para los monocultivos: "en las parroquias Balao y Naranjal, hacia 1921, 12 familias controlaban 30 propiedades”, (Larrea, 2006, p. 29)

El desarrollo cacaotero utilizó la riqueza de los suelos para incorporar mano de obra barata, que venía de la sierra ecuatoriana, debido a que la hacienda serrana entró en crisis y que a comienzos del siglo XX se terminó el sistema de concertaje ${ }^{2}$, es así que algunas formas de concentración pre-capitalistas, permitieron a gamonales de la costa enriquecerse a través del cacao, con muy poca inversión tecnológica. La ampliación de la frontera agrícola, cambio el paisaje de la costa ecuatoriana, grandes extensiones de selva tropical fueron taladas a fin de cultivar el cacao utilizando mano de obra de indígenas, campesinos y montubios pobres.

La concentración de la riqueza en pocas manos debido a la renta diferencial que se generaba de la alta productividad del suelo y la desigual distribución de la riqueza en el proceso productivo, llevó al "conocido "crecimiento empobrecedor", al que hacía referencia el profesor Jagdish N. Baghwati ya en 1958” (Acosta, 2012, p.63).

A mediados del Siglo XX, la siembra de banano representó, en sentido estricto, el intento más serio de industrializar la agricultura ecuatoriana. Bajo la influencia del pensamiento cepalino, del modelo de industrialización por sustitución de importaciones (ISI), los suelos fueron ocupados en grandes extensiones exclusivamente en el cultivo de banano, destruyendo los bosques y sometiendo a la población a una situación laboral muy precaria.

La industria extractiva del banano requirió de grandes extensiones de monocultivo, la utilización del suelo y la devastación de amplias zonas boscosas en la costa ecuatoriana fue evidente, en 14 años (de 1951 a 1968) se devastaron 72.682 hectáreas en la costa ecuatoriana, cambiando el paisaje del litoral.

La industrialización de la agricultura en la producción de banano atrajo la inversión extranjera, los gobiernos militares de década de 1960 captaron inversiones endeudando al Estado; de allí el crecimiento vial, el fortalecimiento de las instituciones públicas y la construcción de puertos; sin embargo y paradójicamente, la deuda sirvió para enriquecer a las oligarquías y la burguesía industrial de las grandes ciudades, como Quito, Guayaquil y Cuenca que experimentaron un sustantivo crecimiento y no para una matriz productiva sustentada en la agricultura, estos créditos “jamás se destinaron a financiar un desarrollo industrial, del cual el Estado, que estaba firmemente convencido de las virtudes del laisser faire, no se preocupaba jamás en la época” (Amin, 1974, p. 214-215).

Mientras la innovación tecnológica operaba en el litoral ecuatoriano, aprovechando la crisis

\footnotetext{
2 "En el sistema de concertaje (los "indios propios" eran también denominados "indios conciertos" en virtud de que habían concertado un contrato entre ellos y el patrón de hacienda), existía un férreo control sobre el tiempo de trabajo y sobre los anticipos entregados a los indios conciertos. La ley posibilitaba la prisión por deudas, y dada la forma particular por la cual los indios se comprometían o "concertaban" con la hacienda, el patrón de la hacienda estaba en capacidad de utilizar la figura de la prisión por deudas para someter a los indios conciertos. En la mayoría de las haciendas existían calabozos y prisiones para los indios que se negaban a cumplir los compromisos asumidos con el patrón." (Dávalos, 2002, pág. 92)
} 
bananera en Centroamérica debido a pestes como la Sigatoka Amarilla y el mal de Panamá, así como a la recesión económica a nivel mundial. En la sierra se industrializaron a pequeña escala las haciendas para la siembra de cereales, papa, hortalizas, lácteos, que atendían la demanda del mercado interno.

\section{LA MÁs RECIENTE PLAGA, PERO NO LA ÚlTiMA DEL MAL DESAR- ROLLO: EL CORONA VIRUS.}

A raíz de la industrialización y del crecimiento económico como el fin último del progreso, acto que ya fue condenado por Aristóteles 384 años A.C cuando se refiere a crematística como el arte de hacer dinero o de enriquecerse y administrar riquezas haciendo dinero del dinero, del interés en el mercado; el desarrollo no ha presentado sino continuas enfermedades en los territorios, sean estos en la salud de la tierra, los animales o los seres humanos.

La reciente enfermedad llamada coronavirus y que la OMS le denominaría COVID-19; que surge en Wuhan - China, es sin lugar a dudas en la opinión de muchos científicos, una externalidad de la destrucción ambiental. Se debe a la presión que ejerce el progreso para deforestar los bosques y sembrar productos que el mercado está demandando, entre ellos la producción de agrocombustibles. Como afirma David Quammen (2020), uno de investigadores sobre las epidemias modernas:

Esto ocurre en zonas de gran degradación ambiental. Los entornos ricos en diversidad biológica, con muchos tipos de plantas, animales, hongos, bacterias, son también lugares que albergan muchos virus. Viven allí, sin ser notados, durante millones de años sin causar ninguna enfermedad, hasta que de repente pasan a los humanos. Y cuando hay degradación ambiental, significa que estamos interfiriendo con ese ecosistema. Estamos cortando árboles, construyendo asentamientos, abriendo minas. (Faleirus, 2020)

La salud de los pueblos de la Amazonía se ha visto deteriorado cada vez en mayor grado, debido a la deforestación, colonización y la implementación de nuevos cultivos que no son los tradicionales de la zona destinados a los agrocombustibles. Para los pueblos de la Amazonía la salud está en la alimentación, buena alimentación significa buena salud, mala alimentación es sinónimo de mala salud.

Según Houtart (2016, p. 25), en el Ecuador ya se han destinado alrededor de 40.000 hectáreas para la producción de caña de azúcar destinada a convertirse en etanol, con financiamiento del gobierno chino, por otro lado, en Brasil se discute la posibilidad de convertirse en la "OPEP de los agrocombustibles, a través de los monocultivos en su Amazonía": Esto es lo que afirma el ingeniero Expedito Parenti: "Tenemos 80 millones de hectáreas en la Amazonía, que se convertirá en la Arabia Saudita del biocarburante”, en: (Houtart, 2011, p. 112).

Si en 1972 en informe Meadows sobre los límites del crecimiento, en su tercera recomendación advierte que la población, la producción y por lo tanto los impactos ambientales están creciendo exponencialmente; no es necesariamente que la producción crece en relación con la necesidad de alimentar a la población, sino como se puede observar en el análisis que realiza Houtart (2011), es para movilizar la industria, los vehículos, lo aviones, barcos, etc. que requieren de combustibles extraídos de los alimentos, debido a la crisis de combustibles fósiles.

La presión sobre los ecosistemas para producir el etanol y el aceite de palma africana, requerida por los países industrializados y negociada por las grandes compañías: Richard Bran- 
son, George Soros, General Electric y British Petroleoum, Ford y Shell Carguil y el grupo Carlyle, entre otras, lleva al desequilibrio entre la naturaleza, los animales salvajes y los seres humanos. "Para acelerar el proceso, en indonesia se procedió a desmontar los campos por medio de fuego, por esta razón fueron incendiadas gigantescas extensiones de tierra en 1997 - 1998" (Houtart, 2011, p.122).

Lo que se observa en el modelo de desarrollo actual es el la población aumenta en condiciones de desigualdad, debido a la mala distribución de la riqueza y a un equivocado estilo de vida que considera al consumismo como el motor del sistema, de esta marera llegamos a niveles ya no solo de desigualdad económica, sino de una enfermedad del propio sistema, un proceso de entropía debido a las plagas generadas por el mal desarrollo, como advierte R-Villasante (2006), que plantea las 4 grandes plagas del mal desarrollo:

El primero sobre el habitar y nuestra mala relación con la naturaleza; el segundo tiene que ver con el trabajo y las consecuencias económicas del desempleo; el tercero sobre los poderes y las formas de organizarnos entre los seres humanos y las violencias que se evidencian, y el cuarto el de las culturas, es la imposición de un pensamiento y forma de vida monolítica (Astudillo y R-Villasante, 2016, p.178)

La mayor parte de las enfermedades como el SARS en Asia, el Ébola en África, o el Corona Virus en Wuhan - China tiene relación, con la deforestación, la industrialización y la urbanización, permitiendo de esta manera que los patógenos y virus muten de los animales salvajes y del amontonamiento de los domesticados, a los seres humanos. La crianza de animales que conviven con los salvajes y que, "esperan a ser llevados al matadero: ...son las condiciones idóneas para que los microbios se conviertan en agentes patógenos letales" (Shah, 2020).

La industrialización desenfrenada ha sido la causa para que la tierra invadida se manifieste a través del desequilibrio, las enfermedades, virus y la actual pandemia se deba a que: "Los bosques son destruidos por las empresas madereras, la población humana crece y el ganado se traslada, los animales salvajes tienen menos espacio. Se juntan. Eso lleva a los virus" (Goodall, 2020).

\section{RECUPERAR LA TIERRA PARA UNA AGRICULTURA SALUDABLE.}

El desarrollo de la agricultura ecuatoriana, va de la mano con la administración y manejo de la tierra y los intentos de conectarse a una dependencia económica favorable, dejándose arrastrar por el desarrollismo y la sociedad agrícola industrial, de corte occidental.

Las leyes de manejo del territorio, favorecen a la industrialización de la agricultura y la inclusión del Ecuador en el mercado, así en 1843, se dicta la ley de tierras baldías, en 1937 la ley de comunas y 1964 y 1972 la ley de reforma agraria, todas ellas destinadas a organizar el territorio y la incorporación de los indígenas a la producción para la satisfacción del mercado a nivel internacional. Estas leyes favorecieron la producción de cacao y banano, concentrando las mejores zonas agrícolas en pocos grupos dominantes y marginado a los indígenas a los peores territorios, tales como: Suelos montañosos, irregulares, improductivos, sin conexión vial, donde se consolidaron poblados empobrecidos, situación que subsiste hasta la actualidad (Guerrero \& Ospina, 2003; Herrera, 2007).

En ningún momento se pensó cambiar la distribución de la tenencia del suelo a través de las leyes, pues estaban claramente establecidas para mantener la desigualdad y la exclusión de 
los sectores campesinos e indígenas: "las primeras, para relegar a los campesinos a las peores tierras, y mantener el despojo, y las segundas, para favorecer la penetración de las formas capitalistas sin alterar la estructura de la tierra" (Herrera, 2007, p. 27).

Debido a la reforma agraria de 1964, en la que los indígenas dejaron de trabajar en las haciendas como huasipungueros ${ }^{3}$, y a la sequía que vivieron poblaciones de la sierra sur y la costa, el Estado promovió una agresiva colonización hacia la Amazonía ecuatoriana, desatando conflictos entre colonos pobres y las culturas ancestrales que viven en dichos territorios.

Para legalizar la propiedad del suelo en territorios amazónicos, se organizó el Instituto Ecuatoriano de Reforma Agraria y Colonización (IERAC), organismo que otorgó títulos de propiedad a colonos que se hicieron adjudicar, territorios ocupados por pueblos ancestrales, como si estos hubiesen estado desocupados, eran "baldíos" según la ley de reforma agraria, aunque estaban ocupador por grupos amazónicos, que no constaban en la ley como ciudadanos.

Las leyes de reforma agraria intentaron frenar el descontento de los movimientos indígenas y campesinos, con la maniobra de concentración, repartición y reconcentración de la tierra en función de implementar la producción para incorporarse a través de las exportaciones al mercado capitalista. Los diagnósticos de la tenencia de la tierra siempre han dado cuenta de la desigualdad y la exclusión de los campesinos e indígenas, aunque en la ley de reforma agraria de 1964, frente a la concentración del suelo en pocas manos, hubo una novedad: "el lanzamiento de la reforma agraria con un objetivo marcado de cambio estructural del agro y la articulación de la reforma agraria con la colonización, como dos facetas de una misma acción” (Gondard y Mazurek, 2001, p. 16). La novedad de la reforma agraria de entregar la tierra a quienes la trabajan no funcionó, ya que entre 1964 y 1994 tan solo se han repartido el 3,4\% de la superficie del país en un promedio de 7,4 hectáreas por unidad productiva.

La situación actual no ha cambiado en la desigual distribución de la tierra: "El 46,3\% de las tierras es de propiedad del 0,68\% de la población nacional. (Houtart y Laforge, 2016, p. 23). El Estado ha cuidado esta estructura sobre la propiedad de la tierra, debido a que su fin último estaba enfocado a la integración del Ecuador con el mercado internacional y en terminar con la modalidad de producción y social oligárquica - terrateniente, opuesta a los ideales del desarrollo y la modernización, según la Ley de reforma agraria de 1964.

Sin embargo, no ha sido posible tal producción con fines integracionistas, aunque en la última década la producción este encaminada hacia la demanda de comoditties, internacionales con fines de satisfacer la demanda de agrocombustibles. Esta situación está concentrada en la costa y la zona andina; en la Amazonía los pueblos ancestrales tienen una demanda totalmente diferente del territorio que es fundamentalmente para su reproducción: Social, agrícola en términos alimenticios, de salud y espiritual.

La desigual inclusión de los campesinos e indígenas al desarrollo agropecuario, donde la participación era fundamentalmente a través de la venta de mano de obra barata, como obreros agrícolas, y no como propietarios de la tierra, fue despertando una conciencia social histórica que estaba en la memoria del pueblo desde la colonización española.

El año de 1992 con motivo de celebrar los 500 años de resistencia indígena en Latinoamé-

\footnotetext{
${ }^{3}$ Huasipungo proviene de dos palabras Kichwa, Huasi $=$ Casa, pungo = Patio, tierra. El Huasipungo fue un sistema de dominación en las haciendas serranas, el amo cedía un pedazo de tierra para que los indígenas, con sus familias instalaran sus viviendas de paja, muy precarias denominadas chozas y alrededor de la misma cultivarán. Los suelos cedidos eran infértiles, carecían de riego y estaban localizados en las laderas, suelo irregular. A cambio de esta concesión los indígenas se veían obligados a trabajar en la hacienda del amo, gratuitamente durante varios días a la semana.
} 
rica, los sectores populares, liderados por el movimiento indígena, encontraron la ocasión para reclamar sus demandas e iniciar una campaña en defensa de sus derechos como pueblos ancestrales, de manera especial la defensa de sus territorios, cultura y cosmovisión. Se despierta desde el Sur una conciencia social global y de solidaridad internacional, que luchaba, en contra de "las celebraciones oficiales de los "500 años"” (Cairo y Bringel, 2010, p. 59).

Giulio Girardi (1994), en su libro el libro: Los excluidos ¿construirán la nueva historia?, sustenta la "irrupción en la historia de los pueblos indígenas, los negros, los sectores populares, como una hipótesis histórica fecunda; como expresión de una utopía que puede ser movilizadora y transformadora” (Girardi, 1994, pág. 299).

Los pueblos del Abya-Yala son los nuevos sujetos históricos y políticos, como advierte Boaventura de Souza Santos en su texto, "la sociología de las ausencias", porque prevé que las nuevas experiencias, no solo que son un faro para la lucha coyuntural, sino que van "expandiendo no sólo el presente, sino abriendo nuevas perspectivas al futuro” (Cairo y Bringel, 2010, p. 45).

El movimiento indígena del Ecuador, y el Ejercito Zapatista de Liberación Nacional al sur de México ${ }^{4}$, expresan su indignación ética ${ }^{5}$ convirtiéndose en brotes policéntricos de la lucha por la recuperación de la tierra y en contra del neoliberalismo; promoviendo el cambio en la estructura de la tenencia del suelo y el reconocimiento de un Estado plurinacional y pluricultural.

La lucha indígena viene desde los procesos por la recuperación de las tierras y la liberación de las condiciones desiguales e injustas que vivían en la colonia; esta indignación y esperanza va consolidándose en la organización del movimiento indígena, negro y popular, con el apoyo de algunas ONGs como el Fondo Ecuatoriano Populorum Progessio (FEPP), Central Ecuatoriana de Servicios Agrícolas (CESA), el programa del Banco Central para fondos de desarrollo rural (FODERUMA), "que vieron en las comunas un factor organizativo básico para apoyar proyectos de desarrollo y la modernización” (Guerreo y Ospina, 2003, p. 132).

Por otro lado, está el aporte de la Teología de la Liberación y pastoral indígena liderada por Monseñor Leónidas Proaño, con una fuerte influencia en toda América Latina. Proaño impulsa la organización de los indígenas, como la ECUARUNARI (Confederación de Pueblos de la Nacionalidad Quichua), la Confederación de Nacionalidad Indígenas de la Región Amazónica del Ecuador, la Federación Nacional de Organizaciones Indígenas y Negras del Ecuador (FENOCIN), las mismas que durante los años de 1986 - 1988, plantean una Ley de Nacionalidades Indígenas del Ecuador.

La organización de la CONAIE en 1986 significó la constitución de un nuevo sujeto sociopolítico, en el escenario nacional, sujeto étnico que no solo reivindica derechos, sino inclusión en la política, empujando la posibilidad de una nueva estructura social. La secuencia de movi-

\footnotetext{
${ }^{4}$ La doctora Rosa de la Fuente considera que los pueblos indígenas en Chiapas, en su organización territorial echan mano de una politización de la misma, pues no es posible una reorganización del territorio si no está de la mano una nueva estructura del estado: "el modelo de autonomía regional pluri-étnica era un modelo de reorganización político-territorial más completo, porque implicaba una reforma constitucional del binomio Estado - nación y, por lo tanto, la creación de una nueva territorialidad política" (De la Fuente, 2008, p.81)

${ }^{5}$ La indignación ética sale del mesianismo dogmático que espera la solución de los problemas a futuro, ya sea a través de fundamentalismos religiosos en la espera que un ser supremo resuelva las cosas y de ser recompensados con un espacio donde no existan las desigualdades, exclusiones e injusticias, así como de fundamentalismos políticos que esperan cambiar la estructura social para iniciar una nueva propuesta de sociedad. La indignación ética recupera la "esperanza a partir de lo excluido, una esperanza a partir de los problemas de la vida (...) lo que se trata es de recuperar el punto de vista del presente frente a las propias estructuras" (Hinkelammert, 2012, p. 128-129)
} 
lizaciones que se dieron desde 1990, y que cambiaron la historia de Ecuador, permitieron, "la visualización de los indígenas como ciudadanos políticos y también como sujetos históricos" (Dávalos, 2003, p. 45).

A partir de los levantamientos, desde 1990 hasta el último realizado en octubre de 2019 no es posible pensar el Ecuador sin la participación indígena, siendo la reivindicación de la tierra su principal objetivo, como reza uno de sus slogans de lucha: "ni una hacienda más" (Guerreo \& Ospina, 2003, pág. 192).

Desde 1996 hasta la fecha la participación de los indígenas a través del partido político Pachakutik, ha tenido sus reveces, pues en la "real política", han tenido que pactar con sectores de derecha, realizar alianzas partidarias con el fin de conseguir escaños de poder político a nivel local, regional y nacional, lo que ha ido disminuyendo la fuerza de la organización indígena ancestral desde las bases. Sin embargo, la lucha por el bien común, la identidad y la defensa del territorio se mantiene en el imaginario colectivo de las nacionalidades indígenas, es así que, en octubre del 2019, cuando el Gobierno de Lenin Moreno (III periodo de la Revolución Ciudadana) intenta alinearse a las políticas del Fondo Monetario Internacional, es nuevamente el movimiento indígena que desde las cenizas se reconfigura con nuevos liderazgos y detiene la Pandemia del economicismo neoliberal imperante en el mundo.

Lo indígena - ancestral subyace en el imaginario colectivo del pueblo indígena y mestizo de América Latina, a esto que Bolívar Echeverría lo denomina como el Ethos Barroco, refiriéndose las formas culturales, de conocimiento y resistencia que mantiene el mestizaje en el mundo de la vida y que, desde la colonia hasta los actuales momentos del neoliberalismo globalizador, han sido utilizados para mantenerse en resistencia. En octubre del 2019, "la marcha protagonizada por los trabajadores, docentes y estudiantes universitarios y que integró a los más amplios sectores ...lanza el mensaje a la CONAIE justedes nos representan! (Astudillo, 2020, p. 63-64).

En conclusión la lucha por la tierra desde los pueblos indígenas ya sea que estén en su territorio, que vivan en la ciudad o que subyazcan en el ethos barroco de los mestizos, es una aspiración legítima que puede impulsar un nuevo desenvolvimiento de los seres humanos, en donde la tierra recupere su capacidad de reproducción en equilibrio con sus habitantes y los habitantes se alimenten como un acto de liberación, en armonía consigo mismos, con la comunidad, con la naturaleza y con el cosmos.

\section{LECCIONES DESDE EL MUNDO DE LA VIDA AMAZÓNICA}

A continuación, se presentan tres relatos extraídos de entrevistas realizadas a profundidad, con el método etno-ecológico que al decir de Toledo y Barrea (2008), promueve una investigación participativa y desafía a la ciencia convencional implicando un paradigma científico diferente, "que propone acercarse a la realidad desde tres dimensiones: el cosmos como un sistema de creencias, el corpus como un sistema de conocimientos y la praxis en los procesos de producción (Astudillo, 2020, p.33)

Se presenta brevemente a los entrevistados, quienes desde la experiencia en el mundo de la vida del pueblo Shuar, en sus relatos dejan entrever destellos de luz para una sociedad pospandemia, COVID 19. 


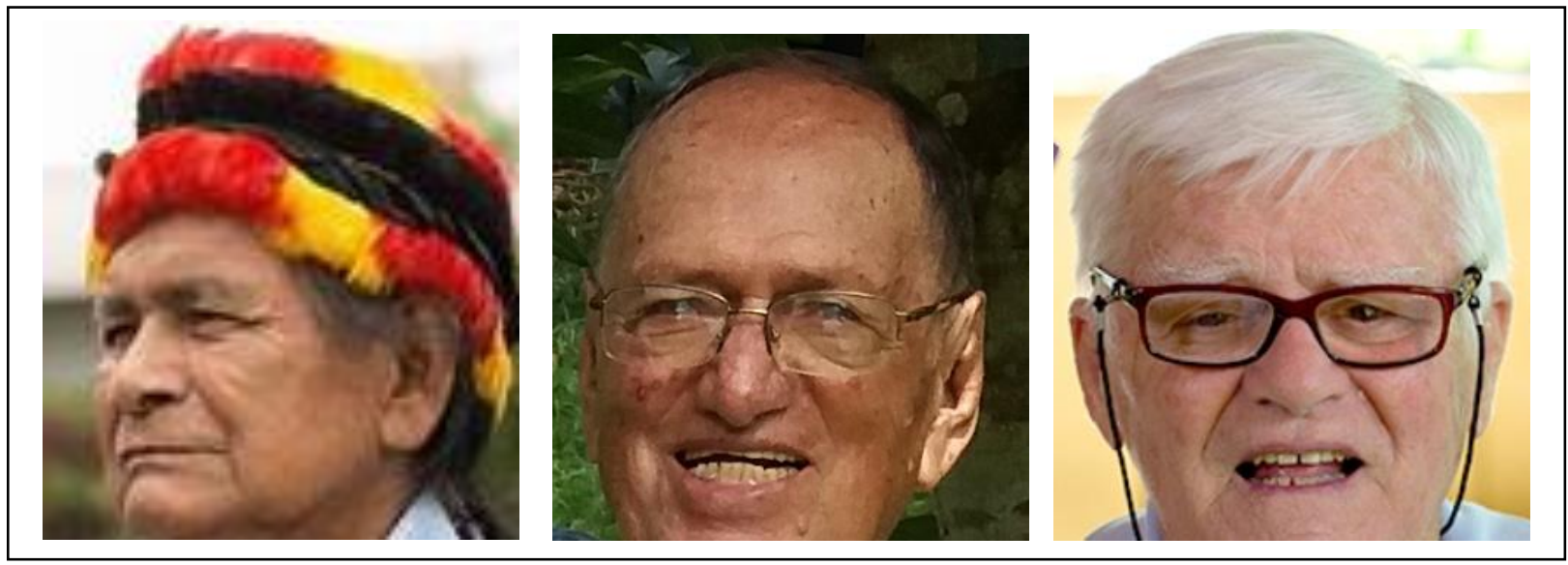

Miguel Tankamash, es un dirigente del pueblo Shuar, fundador de Federación indígena de Centros Shuar (Ficsh), la primera organización en la Amazonía ecuatoriana establecida para defender el territorio comunitario, de la invasión de los colonos y las instituciones del Estado ecuatoriano a través del Instituto Ecuatoriano de Reforma Agraria y Colonización (IERAC).

En 1963, el IERAC entrega al primer presidente, un título individual como "premio" por su lucha, pero él decide renunciar a este derecho con el fin de recibir la tierra bajo el titulo global y hacer prevalecer la tradición de su pueblo, donde el territorio no pertenece a individuos, sino a la comunidad (Astudillo, 2020, p. 133).

Fue el primer presidente de la Confederación de Pueblos Indígenas del Ecuador (CONAIE). Karakras (2018), en una entrevista recoge del propio Miguel Tankamash:

Según los datos registrados de mis padres, nací el 29 de octubre de 1939 en Tuna Chiguaza (Cascada del río chivias) ...Fui inscrito en el registro civil, cedulación e identificación con el nombre de Carlos Miguel Tangamashi Mama, Hijos de jíbaro, Domingo Tangamashi y de jíbara Rosario Mama.

Murió en su parroquia natal Asunción, el 27 de octubre del 2018, a los 78 años de edad.

Miguel Astudillo Guerrero nacido el 13 diciembre del 1934 En la parroquia del Valle, provincia del Azuay, a los 27 años de edad se interna en el sur de la Amazonía ecuatoriana como empleado del Servicio Nacional de Erradicación de la Malaria (SNEM).

Debido a su trabajo en el combate al paludismo hizo mucha amistad con Uwishines (médicos) de diversos territorios del mundo Shuar y Achuar, de esta manera se involucra en la investigación de las plantas medicinales, la espiritualidad y las tradiciones de la cultura y experimenta en su propio cuerpo el alcance de la comida y la medicina Shuar.

El trabajo en la selva en condiciones de extrema humedad y sin tener las condiciones de habitualidad del shuar, pues los trabajadores del SNEM tenían uniformes tipo militar y cargaban bombas de fumigar, así como el manejo de un compuesto químico DDT, deterioraron completamente su salud.

El DDT fue descubierto por Paul Hermann Mulleren 1939, su uso se masificó después de 
la segunda guerra mundial, con el fin de combatir el paludismo, mas tarde algunos insectos como los chinches y hasta en la agricultura, por este uso masivo Mulleren recibió el premio nobel en 1948, por descubrir el veneno contra los insectos, sin embargo:

Rachel Carson, escritora, científica y ecologista graduada del Pennsylvania. En 1962 publicó Primavera Silenciosa donde, con un lenguaje claro y directo, logró transmitir al público los argumentos científicos sobre los peligros que implicaba para el medio ambiente y las personas el uso del DDT así como de otros químicos (Franco, 2008).

Las enfermedades atribuidas a la constante exposición al DDT, tales como cáncer y destrucción del sistema nervioso, fueron parte de la Vida de Miguel Astudillo, que fueron combatidas con las plantas de la selva como él manifiesta:

No es casualidad alguna que la hierbas y las plantas crecen y las flores florecen, Dios, el gran creador del cielo y la tierra, ha designado que esto sea así, para el bienestar de una constante unión entre naturaleza y la humanidad a la cual denominamos unión de vida, fundamental para mantener sanos nuestros cuerpos (Astudillo, 2016)

Miguel Astudillo murió en febrero del 2018 a los 83 años de edad, venció el cáncer y se mantuvo sin dolores corporales de sus múltiples enfermedades, a consecuencia del manejo del DDT y de las extremas condiciones de su trabajo en la selva. Lo que le mantuvo en pie hasta sus últimos días, fue la experimentación en su propio cuerpo de la medicina Shuar, en esa profunda relación que mantuvo con la naturaleza y las plantas.

Siro Pellizaro nació en San Doná di Piave, Italia, 1933, constituye uno de los legados intelectuales más importantes en el mundo Shuar.

Como el mismo manifiesta en una entrevista realizada el 12 de abril del 2016:

Yo me llamo Siro María Pellizaro, soy nativo de Venecia en Italia, pero vine aquí al Ecuador joven, con 19 años. Son 63 años que estoy con los Shuar, entonces algo aprendí de ellos o mucho aprendí de ellos. En cuanto a mis estudios me igualé en Quito, en el Girón, en el bachillerato, porque los estudios de Italia no correspondían al sistema ecuatoriano, estudié Teología en Bogotá unos cuatro años, pero las vacaciones siempre pasaban aquí con los Shuar. Entonces quedé ya definitivamente entre los Shuar desde 1955, quedé aquí en las varias misiones. Sucúa, Méndez, Gualaquiza, adentro en Yaupi, trabajando con los internos, con las familias.

Cuando se escucha al sacerdote salesiano Siro Pellizaro, se puede ir descubriendo en su relato que el interés por entrar en la cultura Shuar no viene de su opción religiosa y peor aún de pertenencia institucional a la comunidad salesiana, en varios momentos relata los problemas que tuvo con sus hermanos religiosos, frente a su comprensión de la cultura Shuar, así manifiesta el en su entrevista: 
Sobre todo, me interesaba mucho conocer la cultura porque en ambientes religiosos se hablaba sólo de supersticiones. Entonces quise ver las tales supersticiones, entonces me interesó la investigación sistemática con los Shuar. Grabé muchas cosas, recogí toda su mitología y vi lo que decían los colonos, como los misioneros, que tenían muy poco de verdad. En realidad, descubrí una civilización muy avanzada y muy rica bajo todos los aspectos.

Esta percepción de Siro Pellizaro es recogida también por el antropólogo Jim Boster, en el proceso de inculturación de Pellizaro, que se deje llevar por los saberes de los Shuar, así como también por su forma de comprender la espiritualidad en relación existente entre naturaleza y humanidad:

me fui convirtiendo a esa cultura; esa cultura me convirtió a mí, en lugar de yo convertirla. Y comencé más a dejar el sistema colonizador, sin imponer nuestra manera de cristianismo, para buscar encarnar siempre más los valores que estaban ya en su cultura (Maurizio Gnerre, 2012, p. 604).

Pelizarro Fue también uno de los fundadores de la Federación Interprovincial de Centros Shuar (Ficsh) junto a Miguel Tankamash, el padre Alfredo Germani y el padre Juan Shutka. Murió después de una fructífera contribución a la investigación con sus publicaciones, así como de compartir saberes con los Shuar, el 13 de mayo del 2019, en el cantón de Sucúa.

Entre el 2018 y el 2019 estos tres personajes: Un líder Shuar, un colono ecuatoriano y un misionero italiano, han dejado de existir, y en las entrevistas realizadas se puede leer muchas lecciones que ayudan a comprende de mejor manera el mundo, la relación entre, naturaleza, humanidad y espiritualidad, justamente en estos tiempos donde el desequilibro y la falta de armonía ha provocado una pandemia llamada COVID 19.

Lo que se expone a continuación son los sabes de estas personas que pueden ayudar a superar un mal desarrollo y el desequilibrio.

\section{RELATOS SOBRE LA RELACIÓN CON LA NATURALEZA:}

La naturaleza en la cosmovivencia del pueblo shuar no está separada de los seres humanos, todo lo contrario ella adquiere una personificación en la relación con la comunidad. La naturaleza cura, alimenta, cuida y sanciona. Los seres humanos son una parte de la naturaleza, de tal manera que si la tierra sufre, se enferma imediatamente se enferma la comunidad y la persona individual. Los dioses no viven separados de los seres humanos, ellos se manifiestan en la naturaleza: Arutam ominpotente vive en la cascada; en la agricultura, el subsuelo y la mujer como Nunkui; como hombre para crear la selva se llama Shakáim; para crear el ciclo de vida entre hombres, animales y plantas se llama Uwí; Etsa es el hijo de Arutam manifestado em los animales que vien sobre la teirra; Tsunki es la manifestación em los animales del agua y la enseñanza de lapesca; Ayumpum em la fecundidade de la mujer la valentia para defender la vida. 


\section{Miguel Tankamash}

Utilizar la naturaleza para la vida de acuerdo la necesidad y la exigencia, o sea servicios de la naturaleza, aprovechar de la naturaleza, no usar de la naturaleza para comercializar, como se hace ahora, tumban árboles para vender. Aprovechamos la naturaleza, la madera que te da para hacer huertos, para la leña, para cocinar, por eso es que la vivienda duraba poco, se pudría la casa, se caía la casa y entonces había que ir a un lugar donde haya vegetación que se llama bosque primario.

El Shuar invocaba al espíritu... en la cascada, invocaba al espíritu en el bosque, de noche, hacía camino, había tremendos árboles e invocaba al espíritu, sabía que el árbol tremendo es espíritu podía darle bendición, comunicarle cómo va a ser la vida, cómo tiene que ser, cómo tiene que vivir, cómo tiene que defenderse, si tiene que defenderse, tiene que hacer justicia porque han matado a sus hijos, matado a su papá, matado a su hermano también... entonces cómo tiene que hacer eso.

La fiesta de la Chonta, su significado de cada año: La naturaleza viene dando la ambulancia, o sea las frutas se cargan, todas las frutas y entonces a eso hay que dar agradecimiento con la fiesta, -sino alguien se va a morir si no agradecen esa bonanza-, por eso es la fiesta de Chonta y cuando se hace la Fiesta de Chonta se hacen ciertos ritos con mucho cuidado, de una forma seria, por ejemplo: El mayor empieza a guiar cantando cómo nace la chonta, chonta nace en cualquier parte llevado por el animal que se llama guatusa, llevado por ave; entonces le botó y empieza a germinar y empieza a salir, crecer y todo esto... hacen el canto y luego empiezan a probar según madura la chicha, toman y hacen la fiesta .

\section{Miguel Astudillo:}

Intentaba llegar a una comunidad por un camino que se demoraba unas cuatro horas, pero yo llegué a descubrir una pica (un tajo), que se demoraba unas dos horas, pero no había camino, una pica nada más, estaba allí una casa donde murió un shuar, la casa estaba botada, entonces yo llego a la casa y encuentro a un niño talvez portecito así (Indica como de un metro), parado ahí, le digo: Oye!, vine caminando por donde caminaba siempre, pero vi otro camino nuevo, ¿por cuál camino está mejor de irme a Santa Rosa? ¿Por aquí o por acá?, me mostro así (señala con la mano), pero no me dijo anda, ni me hablo una sola palabra, solo me mostró y yo como estaba apurado, me dije: El shuar ha de estar sin querer hablar.

¡Un camino de lujo!, para lo que tenía que caminar por lodo, cual fue la sorpresa, a una hora estaba en el río, de ahí salí una hora caminando y otra vez el mismo río, jayayay! ya se quedó lejos el camino, traté de volver otra vez por el mismo camino, ya no pude. Lleno de cortadas por la uña de gato ${ }^{6}$, ique iba a poder volver pues!, Me lancé al río, porque por el río podía bajar hasta toparme con el camino de herradura que conocía. A ratos bajaba caminando y a ratos

${ }^{6}$ Planta medicinal, muy utilizada por Miguel Astudillo, para curar del cáncer y como antinflamatorio para curar artritis y osteoporosis, así como para combatir el Alzheimer. 
bajaba nadando por el mismo río, se podía caminar y se podía nadar. Hasta que ya me canse, anocheció, me salí, ya no podía salir caminando sino igateando, gateando, gateando, gateando!, y me senté al pie de un árbol grande y comenzó un aguacero de esos terribles, entonces me senté ahí y no dormí una sola gota toda la noche por el aguacero, puse el casco para sentarme nada más, pero en eso que estaba ahí, solo cabeceé nomas, (el árbol) me dijo: “A dos cuadras está el camino", ¡chuta! -digo-, y ¿será cierto que a dos cuadras está el camino?, de ahí si camine, camine, camine, cogí el camino camine, camine y caminaba, caminaba unos 15 minutos y tenía que descansar diez porque me hacía ahogar y avance a llegar justo a la casa de un shuarito.

Me vio la mujer como llegué le conté y le dije: ¡dame alguna cosa, sálvame!, ella corrió a calentar chicha, ¡no chicha!: digo, -me ardía la garganta de lo que me ahogaba-, talvez una agua de algo - digo -, entonces ella apuró haciendo hervir una agua de guayusa y me saco los zapatos - yo no podía hacer eso-, me saco los zapatos y me hizo que me ponga los pies a lado de los palos con los que ella cocinaba, de pronto el hijo salió corriendo hacia afuera, estaba llegando el marido, cuando oí que llegó el marido bravísimo yo dije: ¡aquí si me mató!, es que la mujer me puso ahí y como son celosos dije: jacabe con mi vida aquí.

Bravísimo me dice: jestas muriéndote!, me agarró, me acomodó y más me puso las piernas ahí (cerca de la brasa), me saco las medias y de ahí le dijo a la mujer prepárale, me preparó una cosa con bastantes cebollas, me dieron de comer, me acosté. Me desperté como a las 2 o 3 de la tarde, estaba con en un sueño. El niño que le indicó el camino, al inicio - comenta- era un espíritu, pues la casa estaba botada porque cuando los Shuar mueren, les velan en la casa y luego abandonan la misma -comenta-

\section{Siro Pellizaro:}

Ellos son de una creencia animista, la naturaleza es viva, no son más cosas, sino son seres vivientes con los cuales se puede hablar. Entonces nunca sufren el aislamiento, la soledad porque están rodeados, aunque sea un solo hombre puede conversar con la naturaleza. Entonces está siempre en compañía.

La naturaleza la conocían al dedillo porque vivían de ella. Entonces conocían de cada planta para qué servía, que nombre tenía, cada hierba, etc. Entonces tenía la medicina natural porque descubría en la naturaleza lo que servía para curar. Tenían un conocimiento, sabían que cosa se comía. Eran buenos cazadores porque sabían que animal va a comer tal fruto, sabían la comida de cada animal. Entonces cuando quería cazar un animal iban cerca de una planta, abundancia de caza.

Tenían el río, conocían todo del río, la agricultura, tenían la huerta. Muchos creían que eran nómadas, ¡no!, nunca han sido nómadas porque un nómada vive sólo de lo que encuentra en la selva, mientras que ellos tenían una casa fija, una huerta fija, producción agrícola.

No dependían de un mercado, porque todo tenían, su estructura es de autosuficiencia y de subsistencia. Ellos mismos se hacían el vestido, sabían tejer. Ellos mismos hacían todas las ollas que necesitaban con el barro. Tenían su herra- 
mienta de trabajo, aunque sea de piedra, eran autosuficientes.

Nosotros los misioneros promovimos la Federación porque con Velasco Ibarra, éramos tutores legales del shuar y como tutores habíamos pedido unas reservas para que el shuar tenga su territorio para vivir independiente de los colonos, porque los colonos invadían todo. Entonces más o menos en los años 64, 65, terminaba esta tutoría y los colonos eran siempre más hambrientos de las tierras shuar. Terminada la tutoría iban a invadir las tierras del shuar, por eso creamos la Federación. Animándolos, así: Ahora nosotros hemos sido tutores y ustedes deben ser independientes. Para ser independientes deben defender sus tierras, su territorio, pero legalmente hay que defenderlo.

Entró la idea de formar los centros shuar. Los centros shuar era una denuncia global del territorio, donde todos los que vivían dentro de esa denuncia tenían personería jurídica. Así creamos esas estructuras (Federación Indígena de Centros Shuar), promovimos también la ganadería y llegaron a tener una estructura y un bienestar también en aquel período, en los años 70 - 80. Con esa estructura, aunque los colonos querían entrar no podían en una denuncia global porque era un contrato.

\section{RELATOS SOBRE LA PRODUCCIÓN Y LOS ALIMENTOS.}

A través de la tierra el Pueblo shuar adquiere sus alimentos, no es de su interés la acumulación, sino la subsistencia, el alimento que permita la reproducción de la vida, satisfaciendo las necesidades básicas de: Alimento, salud, recreación, trascendencia y ritalidades, tal y como lo hacen cuando preparan la chicha de yuca como bebida alimentícia o la chicha de chonta como un ritual de agradecimento por la fertilidad.

La defensa del territorio es uno de los mayores objetivos de la población shuar, pues el estado toda vez de respetar su espacio de vida ha invadido para la explotación de madera, la introduciión de la coloniozación, la explotación petrolera desde inícios de los años 70 y últimamente están invaniendo los neocolonizadores bajo la figura de las grandes empresas transnacionales que explotan la minería metálica para el mercado de los comoditties, como expresa Maristela Svampa.

\section{Miguel Tankamash}

El indígena amazónico no siente el problema, dice: yo soy pobre porque no tiene plata nomas; pero él tiene tierra para comer, para no morir de hambre, lo que hace falta es la platita, a ellos que les importa el problema del país... no hay en la sangre la plata. El mestizo duerme pensando en la plata, despierta pensando en la plata, ¿sí o no? El selvático no piensa en la plata... no le importa el cultivo (para el mercado), tiene para comer y ya es suficiente... (algunos indígenas) andaban en comercio de ganados, mercaderes que andan cambiando cosas. Entonces ellos traficaban, vendían ropa.

¡Ahí está la reserva! (nos dijo el gobierno). Digo: ¡estás hermano equivocado!, ahora hay que defender la montaña porque eso es vida para el pueblo, para el mundo entero, el oxígeno hermano... Más bien hay que defender eso y todo el 
mundo es gente que piensa, ama la vida en el mundo. Hay que defender el bosque porque purifica el aire. Hermano hay que tecnificar nuestra producción; con lo que tenemos hay que producir, mejorar la calidad del ganado; ¡eso sí hay que hacer!, pero para eso necesitamos educación de calidad para nuestros hijos, así le dije. Yo le digo hermano, primero no sabes, segundo no tenemos reserva, todo es con título global reconocido judicial y legalmente, por ley; entonces no tenemos ninguna reserva, el territorio es con título global.

\section{Miguel Astudillo:}

Las plantas tienen poderes, toda planta tiene poderes, todo medicamento natural vivo es más efectivo que los elaborados, estos son medicamentos muertos, no es lo mismo que arrancar a una planta una hoja, que tomar pastillas, entonces eso me ha servido mucho a mi para poder, aprender algo, para poder ayudar y poder seguir ...los shuar me enseñaban a preparar, decían: veras, si comes una gallina ya preparada en maggi no es lo mismo, pero si matas una gallina y te comes esa gallina fresca es una buena preparación, lo otro ya está muerto, ya está procesada cuantas veces y no es lo mismo, entonces lo que me enseñaban los shuar es a buscar los medicamentos, como buscarse los alimentos frescos como ellos lo hacían.

\section{Siro Pellizaro:}

Para alejar los ratones como plaga en la huerta, había una celebración de Katíp, o sea del ratón. Para alejar las plagas había una celebración.

Ahora nosotros nos reímos, pero yo fui testigo de una plaga de ratones, que después no vi más. En Yaupí en 1956 hubo una invasión de ratas. Me levanté de mañana en el patio había como 30 ratas agresivas, había que salir con un bastón para que no lo vengan a morder estaban hambrientas. En una semana eran miles, miles de ratas que llegaron de golpe de la selva, acabaron con todas las huertas de la zona, tanto de la misión como de los particulares. Tanto que tuvimos después que se fueron las ratas, que volver a sembrar de nuevo. Y vivir como 5-6 meses hasta la nueva producción, nada más con hierbas y pescado. Habían acabado todo. Entonces ahí cuando llegaba esas invasiones había una celebración para pedir que aleje esa plaga. Todos rezaban juntos. Había varias celebraciones.

Para que descanse, el suelo se usaba sistemas de rotación de la agricultura, donde colaboraba toda la familia, unos trayendo los postes, otros la paja, etcétera. Colaboraba toda la familia en la construcción de la casa, luego cada uno arreglaba su casa. Cuando se agotaba la huerta iban a otro lugar, los que no conocen bien, dicen son nómadas porque dejaron el lugar. ¡No!, deja esta huerta y hace otra en la misma zona. Hacen otra huerta y otra casa.

En su cultura ni se imaginaban que no pudieran tener comida, porque el vestido lo hacían ellos, la comida la producían ellos. El que no producía era mal visto como ocioso, nada más, (risas). 


\section{RELATOS SOBRE EL RESPETO AL OTRO, INTERCULTURALIDAD Y DIÁLOGO DE SABERES}

Respetar al otro implica que el ser humano no debe sentirse superior a los demás, a lo que le rodea. Para ello es importante que las personas se sientan parte integrante de la naturaleza saliendo del egoísmo antropocéntrico, que pone al hombre como el elemento más importante sobre toda la vida.

En la cultura shuar hay respeto por los animales, las plantas, el agua, la comunidad, las otras comunidades y culturas mientras vivan en sus territórios. La colonización ha sido el instrumento bajo el cual se ha dominado, explotado y agredido un territorio donde las culturas convivian.

Hoy más que nunca hace falta un diálogo sustentado en el respeto de las diferentes culturas que habitan en el território de la amazonía ecuatoriana, solo aquellos y aquellas que han superado las visiones occidentales de superioridad: Racismo, concepto civilizatorio basado en la destrucción de las tradiciones y de la naturaleza para el crecimiento, han logrado establecer este diálogo necesario.

\section{Miguel Tankamash:}

Nosotros creemos y empezamos a hablar de la multiculturalidad y plurinacionalidad, porque habemos diferentes pueblos con conocimiento, con capacidad para vivir, tratamos de vivir bien y ayudarnos, hay que apoyarnos para vivir bien, que haya respeto de la vida, de toda persona humana, que haya respeto de derechos humanos; eso es la propuesta de utilizar el término de plurinacionalidad.

Las relaciones pluriculturales eran esto: Nosotros somos Shuar, tenemos nuestra propia cultura en alimentos, en la forma de aplicar la medicina y la forma religiosa y respetamos a otras culturas que tienen también su mundo, su forma de salud, de convivencia, etc., somos tantos pueblos que vivimos aquí, que esto sería pluriculturalidad... ¿un buen vivir?: Cada cual lo que hacen, está bien, cada pueblo si está conforme con lo que tiene, está bien, no hay porqué exigir a nadie.

\section{Miguel Astudillo:}

Los curanderos shuar dan el poder cuando miran a la persona, cuando saben que la persona realmente va a poder ejercer esa función, si no tiene la energía positiva en vez de hacer un bien le enferma a otra persona.

Yo comencé a curarme desde que me dolían las enfermedades, entonces vi que yo sufría y no me curaba, me dijo una vez un amigo shuar: Vos puedes ayudar, ipuedes ayudar!, pero concéntrate, entonces cuando veas que si puedes ayudar hazlo, pero si ves que no estás en condiciones no hagas, porque luego no vas poder ayudar y lo que vas a hacer es daño. Vi que podía ayudar, cuando estaba tomando ayahuasca, con un amigo shuar, esto fue detrás de la cordillera Kutucu, con uno de los verdaderos, verdaderos curanderos; ellos vivían de la vegetación. El curaba (con las plantas) y yo, estaba curando a personas del paludismo con pastillas, y me dije: ¿Por qué no podemos ayudar a personas con 
esto? (con plantas), era un brebaje a base de jugo de ortiga y ayahuasca.

Hice un preparado y le di a una persona que estaba con paludismo, no le avise que el tenía paludismo, como yo mismo controlaba cuando le tomaba los exámenes, y bueno le dije: Usted tiene otro problema de salud, así es que va a venir a verme a cada rato, cada que venga va a tomar el licuado que le preparé, y le iba controlándole, al mes salió negativo, a los dos meses negativo, a los tres meses negativo (Se curó del paludismo con el brebaje)

La relación entre curanderos hizo que se me vea como persona sincera, yo nunca he sido abusivo o aprovechador de las cosas ¡no!, en donde yo estuve, la misma corona para todas las personas, así he demostrado confianza conversando. Nunca he necesitado que me digan ni doctor, ni nada, sino del nombre, ¡amigo toda la vida!, ellos conmigo fueron: ¡hermano! ¿cómo estás?, ¡hola, hola! ¿cómo estás?, luego cuando yo iba a una casa: ¿señora como esta?, así sea una viejita shuarita que este por ahí, señora que merece respeto: ¿cómo esta señora? Ellos también me daban confianza, me hacían entrar a la casa conversábamos, sobre la medicina y conversábamos sobre lo que yo sabía, que rituales hacen para la curación, que rituales hacen para las peleas, que ritual hacen para descubrir los enemigos, todas esas cosas, todo era a base de alucinógenos que ellos tomaban.

\section{Siro Pellizaro:}

En todo aquel tiempo se hablaba de salvajes, brutos, cortadores de cabezas, y todo eso, entonces después investigando me di cuenta que no eran ni brutos, ni cortadores de cabeza ni como decían polígamos, animales, nada, de eso que está escrito en muchos libros de antropología, todo eso no es cierto. Vi que pertenecen a la humanidad, que son hombres como nosotros, que piensan, que razonan, que estructuran, que viven dentro de una estructura creada después de mucha experiencia.

Yo descubrí que en su estructura social eran muy felices, que vivían muy bien, pero al tomar contacto con nuestra cultura y al ser despreciados, han empezado a tener vergüenza, quisieron hacerse a nuestra cultura, cosa que ellos hasta ahora no comprenden, porque no hay comparación, de los valores, no comprenden nuestros valores porque no está en relación con sus valores. Entonces es un copiar vaciándose espiritualmente y comenzando a entrar en la pobreza, porque botan todas las estructuras que les hacían vivir bien.

En la medida que botan la cultura, botan todo, ¿no? (risas). Entonces no saben más hacer su vestido, deben ir a comprar, no saben más hacer sus ollas, deben irlas a comprar. No va más a lavar sal, sino la compra. Entonces se hace TOTALMENTE dependiente de la cultura envolvente. Totalmente porque no produce nada para ganar y después comprar, sino solo depende. Se transforman en obreros de los colonos sobre todo en vaqueros, pierden su independencia, dependen de lo que alcanzan a ganar para comer, si no come debe transformarse en ladrones ¿no? ... jentonces! 


\section{RELATOS SOBRE LA SALUD Y LA ESPIRITUALIDAD}

Lo que evidencia la pandemia del corona vírus, es la enfermedad de la tierra, el miedo a los otros, el temor de acercarnos, de contagiarnos debido al individualismo y consumo al que nos ha llevado el sistema vigente.

La salud no es un hecho aislado a la paz del individuo y de la comunidad. No se puede estar sano individualmente, eso es evidente en esta pandemia. Para los shuar la salud es un tema comunitario, incluso lo que occidente llama problema social como el robo, la delincuencia, para el shuar es considerado como un problema de mala salud espiritual. Así por ejemplo cuando alguien roba, agruede a su mujer, es llevado a un ritual de curación del espíritu.

Tal vez la sociedad actual no solo se enformó del espíritu, sino que lo opacó, intentó apagarlo. Pero el espíritu nunca muere, incluso cuando la persona perece su espíritu trasciende en las plantas, en el agua, en las estrellas, etc. Este es uno de los elementos centrales que al país de Bután le ha permitido desarrollarse a través de la Felicidad Interna Bruta, más que del Producto Interno Bruto.

Salud integral y espiritualidad es lo que puede llevarnos a una sociedade pos-pandemia y pos-desarrollo.

\section{Miguel Tankamash:}

Tomar la guayusa es como aseo, por ejemplo, el Shuar o más que todo el Achuar es acostumbrado a tomar guayusa para limpiar el estómago, limpiar las glándulas salivales, aquí se limpiaba las glándulas para tener fuerza para soplar.

En la espiritualidad para que haya bendición tiene que tomar malicahua o ayahuasca, pensamos que ahí el espíritu le va a bendecir, eso es lo que piensan y toman. Ahora la mayoría van a la iglesia, son cristianos, católicos; en esta época llegaron en cantidad los evangelistas, no sé por qué, antes no venían tanto, ahora vienen a cada rato, vienen y van, visitan, hablan de lo que es bueno... iQué van a ayudar a la comunidad!, más bien hacen daño, claro les dan (a los participantes) diez dólares, veinte dólares porque diosito está ayudando, por eso están convirtiéndose más de católicos a evangelistas.

\section{Miguel Astudillo:}

Los medicamentos ellos lo hacían, tomaban la ayahuasca y ellos soñaban o a su vez en sentido vivo, digamos sin dormir, ellos estaban viendo cual es, qué clase de medicamento pueden utilizar para qué clase de enfermedad, en las plantas ellos sabían que sirven para esterilizar a las mujeres, para fecundar a las mujeres. Lo que no tuve la suerte de poder descubrir es como preparar para que las mujeres en el período menstrual no boten sangre porque para ellos era una enfermedad, pero tomaban ese medicamento y con eso no botaban la sangre, menstruaban mas no sangre.

La preparación de la ayahuasca, se le trataba de coger el palito más grueso 
que estaba, se le cortaba en pedacitos pequeños y le golpeaban con una piedra, con una piedra asentada en otra para que este bien chancadita, le cocinaban, como no tenían recipientes grandes, más menos tenían un recipiente de un galón a dos, ahí cocinaban, de ahí el agua iba secándose y ellos agregan más y más y cocinábamos desde las ocho de la mañana hasta las 7 u 8 de la noche, todo el día hasta cuando quede la ayahuasca como miel, eso era lo bueno.

Para tomar ayahuasca, yo hice un día de ayuno nomas, yo no he tomado para hacer curaciones, yo tomaba es por mi salud y por ayudar a ciertas personas, pero no, nunca pensé en decirle si esta brujeado y tengo que sacarle la brujería.

Algunos sabían que estaban con problemas de salud. En Sucúa curé a algunas personas como se comentaba bastante al Robin Vélez, le cure cuando estaba mal, él estaba ya desahuciado de los médicos, decían que él tenía esa enfermedad incurable, estaba botado, en verdad ya le pusieron en un lugar para que muera y para la suerte de él y mía no hubo complicaciones. En tres semanas ya caminaba, porque él estaba sin poder ni caminar, él no sabía que tomaba ayahuasca. Un shuar le dijo que estaba embrujado, el doctor le dijo sabe que ya no hay remedio, él tenía mucha fe el me hizo la propaganda.

El confió, porque yo llegaba así con barro, con ortiga, la cama se ensuciaba y le ponía sumo de huando, unas capitas de mentol chino también y le daba unos buenos masajes y una pierna según él estaba bailando (totalmente floja) y le cogí y le envolví bien los pies con una tela hasta que amanezca y así poco a poco iba soltándose, así pudo caminar y entonces me sentí tan contento el haberle podido ayudar y él también se sentía bastante contento.

Para mis enfermedades preparé con orina, porque leí un libro de orino terapia, que tiene poderes fantásticos, al utilizar en la parte interna, tiene que estar la persona con una buena alimentación, nada de cosas cálidas, nada de bebidas alcohólicas, tabaco, nada de eso. El primer chorrito, se bota y el último tampoco se bebe, la orina debe estar sin mal olor. Escuché una vez una discusión de dos médicos, uno le tomaba como una impureza, decía: ¿cómo puede utilizar la orina? que es una cosa mala, el otro le decía: hay que ver que la orina es parte de la sangre, donde están una serie de vitaminas, es rica en vitaminas la orina, porque se desprende, del cuerpo, de los ojos.

Nuestro cuerpo, tiene bastante líquido, ¿qué hacemos nosotros?, es como estar es una destilación, sale y vuelve, sale y cuando vuelve estamos fortaleciéndonos, en lo interno. Para el uso externo, se utiliza para hacer baños. Yo reuní en una botella con una tapita de hoja de plátano porque dice que las hojas de plátano son como gas, le puse un tanto de ayahuasca, le hice hervir en la alcantarilla hasta que quede en una botella de cristal poquito y esa esencia de lo que quedó me aplicaba donde me dolía.

También para los dolores es bueno huando, así y cuando está bien raspadito entonces eso se agarra se exprime bien, bien y sale bastante zumo, de ese zumito yo le preparaba con zumo de ortiga, le ponía a calentar y eso me aplicaba. Dicen que las plantas ahuyentan, a los malos espíritus y malas energías, tales como: El huando, la ruda, altamisa.

En la medicina hay que ser consientes, si hacen con una mala conciencia o se 
preguntan: ¿cuánto le voy a sacar por hacer esto? o ¡este tiene plata! La medicina tiene que ser curando el cuerpo, pensando en algo espiritual y que no sea de lucro, para Dios nada es imposible, con el poder de él uno se alcanza tantas cosas.

De mí, muchos médicos se han reído cuando les he contado sobre los medicamentos que he preparado para mi cuerpo: ¿Qué medicamentos ha tomado usted?, Si su enfermedad es de mucho dolor y dice usted que no le duele, ¿cómo no le va a doler?, me río cuando los médicos me dicen que me debe doler, porque me he curado y he controlado el dolor.

\section{Siro Pellizaro:}

El shuar era pura espiritualidad digo yo (risas). Es que ahora el shuar ya no son más shuar porque no tienen más espiritualidad.

Si un chico robaba, cosa rara, pero si cogía cosa ajena, tenían un rito, pero nunca se hablaba de castigo, sino de maldad.

Robó porque entró en él un espíritu malo. Entonces ese espíritu malo, ¿con qué se saca?, pues con el humo de ají, se ponía una hoguera con bastantes ramas de ají. Le tapaba con una cobija sobre ese humo, respirando ese humo que es tremendo -si está demasiado tiempo hasta se muere uno-. Con eso le quitaba, le hacía salir ese diablo, entonces ese joven no robaba más toda su vida.

Como que tienen un espíritu malo. Entonces hay que sacar ese mal. No robó. No se concibe que un hombre robe. Si roba es que un espíritu malo lo ha hecho robar, hay que sacar ese espíritu malo, no hay calabozo.

Hay un rito para sacar ese mal espíritu. Entonces uno queda otra vez valorizado. A un chico, por ejemplo, nunca se le pega, se usaba la ortiga, le ortigaban para que deje el capricho, eso era la educación.

Ahora si una persona de adulto, que debe tener toda la formación; se le encuentra con una mujer ajena, se lo mataba, a él y a la mujer. A un adulto que lo encuentren robando, lo mataban. Porque ese no merece vivir, no es hombre. Allí hay toda la mitología que dice: fue maldecido, etcétera, se transformó en animal, todo eso quiere decir que debe morir y no renacer como hombre sino como animal. Porque no merece ser hombre.

El shuar tiene muchas celebraciones, en toda la cultura está Dios, Arutam le llamaban. Por eso mis libros yo los titulo Arutam 1, Arutam 2, 3, 4, 5 . Porque no se puede imaginar la cultura sin Arutam. Todas las veces que tenían una necesidad debían llamar a Arutam.

Había oraciones personales, oraciones de la chacra, cuando la mujer iba a la chacra tenía un montón de oraciones. El hombre de caza tenía un montón de oraciones a Etsa, para la pesca. Si había hijos que no vivían tan bien se lo llevaba a la cascada para coger la fuerza de Arutam y liberarse de esas debilidades, El mismo papá lo llevaba.

Había cosas que eran más comunitarias, que tienen que ver con todos. La oración comunitaria que se hacía todos los años era la de Uwi, la de la chonta. Porque Uwi es Arutam. Arutam que da la vida, que mantiene la vida. Cuando cosechaban la chonta era fin de año para ellos, no es en enero. Con esa chonta 
se hacía una chicha e invitaba a todo el grupo que vayan a pedir a Uwi por un nuevo año, la vida por un año más. Para pedir la vida, todos se cogían de la mano alrededor del poste de la casa e iban rezando, cantando con una danza, llamando a Uwi que haga nacer, crecer todo lo que se siembra, que haga madurar, etcétera. Eso era anual esa celebración con todo el grupo.

\section{CONCLUSIONES}

Las desigualdades a nivel: Económico, social, desarrollo cultural, participación e inclusión política, imposición de sistemas religiosos y pérdida la espiritualidad, perdida de territorio como elemento fundamental para la reproducción de la vida, son consecuencia del sistema de mal desarrollo adoptado por el Ecuador, como herencia colonial y como imaginario del progreso desde la falsa independencia como república.

Las nacionalidades y pueblos indígenas, donde según algunos autores entre ellos Víctor Toledo, se encuentran luces para salir de la enfermedad del mal desarrollo, son las que mas han sufrido las consecuencias el empobrecimiento, llegando en muchos lugares a una vida miserable.

Con la pandemia del COVID 19, queda demostrado el fallido intento del sistema capitalista mal desarrollador por encontrar un progreso en determinados sectores sociales que puedan ser inmunes a la inseguridad, la falta de alimentos y las enfermedades. Todo está interconectado en el ambiente y a nivel social se puede observar que la riqueza depende de la pobreza y que es insostenible el crecimiento a través del PIB, incrementando la desigualdad según el índice de Gini, jambos pueden colapsar, pobreza y riqueza!

En los relatos se puede leer que una salida a la crisis es la vuelta a la convivencialidad territorial. Como asegura Raúl Zibechi: "Estamos en un campo de concentración a cielo abierto y en la medida que el capital descubra que sigue acumulando teniéndonos encerrados, este es un negocio redondo". Los sistemas de salud y producción ancestral ayudarán a combatir las enfermedades y las crisis que se nos vienen a reglón seguido de la pandemia.

En los relatos podemos leer que la cultura shuar tenía una economía de lo suficiente. Cuando los habitantes de la selva pensaban en ubicarse en un lugar su primera actividad no era construir la casa como lo más importante sino analizaban el territorio para cultivar la huerta, pescar y cazar, así la vivienda era uno de los elementos que le permitía habitar el territorio, al contrario de la cultura consumista actual que construye la vivienda sacrificando la madre tierra, que le provee de alimentos, del agua y un aíre puro.

La salud y la espiritualidad son procesos para la sanación y el equilibrio personal y desde ese estado ayudan a los demás. No se piensa en lucrar con los conocimientos, pues de esta manera se entiende que a un Uwishin (médico shuar) se le pagaba con alimentos, animales, etc.

Las comunidades shuar por donde han caminado los sabios entrevistados para este artículo, coinciden que ahora se baten entre su propia extinción y sobrevivencia, la cual no depende solo de los medios materiales, sino fundamentalmente de un proceso de despojo de la mala cultura adoptada para sus vidas, pues así manifiesta Pellizaro, (2016) "Ahora viven vacíos, botando su cultura, solo copian cosas que no tienen valor”. Aún más lapidario es Miguel Tankamash (2016) quien en sus últimos días repetía constantemente la frase de Simón Bolívar: "He arado en el mar", cuando manifiesta: "hermano, ahorita el ser shuar, te digo así textual- 
mente, ya está dominado y todo lo que sea dominado tiene que desaparecer hermano, aunque me duela te digo eso. Ninguno de estos jóvenes habla en lengua shuar". Para Miguel Tankamash la lengua es uno de los elementos de la cultura más importantes para recuperar, como el mismo dice el SER SHUAR.

Si todo lo que está dominado tiene que desaparecer para el primer líder indígena de los pueblos amazónicos y de la Confederación de Nacionalidades Indígenas del Ecuador (CONAIE), entonces hay que iniciar un proceso urgente de descolonización y de vuelta al territorio, con una actitud de respeto y de convivencialidad.

\section{BIBLIOGRAFÍA}

ACOSTA, Alberto. Breve historia económica del Ecuador. Quito: Corporación editora nacional, $1997 / 2012$.

AMIN, Samir. La acumulación a escala mundial - crítica de la teoría del subdesarrollo. Madrid: Siglo XXI Editores, 1974.

ASTUDILLO, Miguel. La selva cura. Wekain. Macas, GAD provincial Morona Santiago, edición 1, enero 2016

ASTUDILlO, José. Prácticas del buen vivir: Experiencias en comunidades Shuar, Kichwa y Manteña. Quito: Abya - Yala, 2020

ASTUDILLO, José. La fuerza de la palabra. En: SALTOS, Napoleón; et al. Octubre. Quito: El Árbol de Papel, 2020, cap. 8, p. 56 -75

ASTUDILLO, José; et al. La participación social en la planificación y gestión de los presupuestos para el buen vivir. La experiencia del gobierno autónomo descentralizado de la parroquia Santa Ana En: ASTUDILLO, José; R-VILLASANTE, Tomás. Participación social con metodologías alternativas desde el Sur. Quito: Abya -Yala, 2016. Cap. 8, p. 175 - 205

AYALA, Enrique. Nueva historia del Ecuador. Vols. 7-12. Quito: Corporación Editora Nacional / Grijalbo, 1993.

CAIRO, Heriberto; BRINGEL, Breno. (2010). Articulaciones del Sur Global: Afinidad cultural, internacionalismo solidario e Iberoamérica en la globalización contrahegemónica. Geopolitica (s). Madrid, Vol. 1, 2010, número 1, p. 41-63, novimebre 2010

DAVALOS, Pablo. Plurinacionalidad y poder político en el movimiento indígena ecuatoriano. OSAL, Observatorio Social de América Latina, CLACSO, no. 9 año III, p. 43-50, enero 2003

DE LA FUENTE, Rosa. La autonomía indígena en Chiapas un nuevo imaginario socioespacial. Madrid: Catarata, 2008.

FALEIRUS, Gustavo. "La destrucción de la naturaleza es lo que nos pone en contacto con los virus": David Quammen. Periódico E1 Espectador. Colombia, 15 de abril. Disponible en: https://www.elespectador.com/coronavirus/la-destruccion-de-la-naturaleza-es-lo-quenos-pone-en-contacto-con-los-virus-david-quammen-articulo-914730. Acceso en 20 de mayo 2020.

FRANCO, Julia. Historia del ddt. Ecologistas en acción. Andalucía, 8 de octubre del 2008. Disponible en: https:/ /www.ecologistasenaccion.org/16473/historia-del-ddt-i/

GNERRE, Maurizio. Los salesianos y los shuar construyendo la identidad cultural. Em La presencia Salesiana en el Ecuador. En: VASQUEZ, Lola et al. Perspectivas históricas y sociales. Quito: Abya-Yala, 2012, p. 573-635 
GIRARDI, Giulio. Los excluídos: ¿Construirán la nueva historia?. Managua: Nicarao, 1994.

GONDARD, Pierre; MAZUREK, Hubert. 30 años de reforma agraria y colonizacion en el Ecuador: 1964-1994. Dinámicas territoriales: Ecuador, Bolivia, Perú, Venezuela, Estudios de Geografía. Quito, vol. 10, colegio de geógrafos del Ecuador, 2001, p. 15 - 40

GOODALL, Jane. La falta de respeto hacia los animales es lo que ha causado esta pandemia. Ultima hora. Panamá, 15 de abril, 2020. Disponible en: https://www.oxitocinamagazine.com/2020/04/jane-goodall-la-falta-de-respeto-hacia.html?m=1. Acceso en: 20 mayo 2020

GUERRERO, Fernando; OSPINA, Pablo. E1 poder de la comunidad: Ajuste estructural y movimiento indígena en los andes ecuatorianos. Buenos Aires: CLACSO, 2003.

HOBSBAWM, Eric. En torno a los orígenes de la revolución industrial. Décima ed. México: Siglo XXI, 1980.

HOUTART, François. El escandalo de los agrocombustibles para el sur. Quito: Ediciones La Tierra, 2011.

HOUTART, François; LAFORGE, Michel. Manifiesto para la agricultura familiar campesina e indígena en Ecuador. Quito: Instituto del Altos Estudios Nacionales, 2016.

HERRERA, Stalin. Percepciones sobre la reforma agraria. Análisis de discursos de dirigentes de organizaciones campesinas e indígenas. Quito: SIPAE, 2007.

HINKELAMMERT, Frank. Lo indispensable es inutil. San José: Arlekín, 2012.

KARAKRAS, Ampam. Miguel Tankamash y la lucha shuar. Quito: Artes gráficas SILVA, 2018

LARREA, Carlos. Hacia una historia ecológica del Ecuador: propuestas para el debate. Quito: Corporación Editora Nacional, 2006.

SHIAH, Sonia. Contra las pandemias, la ecología. Le Monde Diplomatique. Francia, marzo, 2020. Disponible en: https://mondiplo.com/contra-las-pandemias-la-ecologia. Acceso en: 18 mayo 2020 